\title{
MEASURING ADVERTISING EXPENDITURE EFFECTS ON THE NIGERIAN ECONOMY
}

\author{
Shafiu Ibrahim Abdullahi and Shuaibu Mukhtar
}

\begin{abstract}
This study explores relationships between annual advertising expenditure and major macroeconomic variables in Nigeria. Advertising is sometimes viewed as a concern of business units only not worth being researched at macroeconomic level. This nature has been mostly studied on advertising industries in the advanced economies. Due to a lack of high frequency time series data on advertising expenditure in the developing economies, this work has been limited to an exploratory study using the multiple regression and correlation analysis. The study covers the period of 2001 to 2018. Its findings show that advertising has positive relationship with GDP and savings. This study provides further evidence on the cyclical nature of advertising that moves with the state of the economy. During the economic slowdown in the period of 2015 to 2017, Nigeria advertising expenditure continued to fall. In 2013, the period with the highest advertising revenue in the study, the ratio of advertising expenditure as percentage of GDP accounted for $0.061 \%$, which was below $0.2 \%$, a very negligible number indicating more scope for growth in the market.

Keywords: advertising expenditure, macroeconomic variables, correlation, regression, GDP, consumption, inflation, stock market capitalization, savings and FDI
\end{abstract}

JEL Classification: O3, M3, L1, E3, D8

\section{Authors:}

Shafiu Ibrahim Abdullahi

Bayero University, Kano, Nigeria

E-mail: shafiuibrahim@gmail.com

https://orcid.org/0000-0003-3471-4493

\section{Shuaibu Mukhtar}

Kebbi State Polytechnic, Dakingari, Nigeria

E-mail: mukhs001@yahoo.com

https://orcid.org/0000-0002-9924-7323

Citation: Shafiu, I. A. and Shuaibu, M. (2020). Measuring Advertising Expenditure Effects on the Nigerian Economy. Virtual Economics, 3(3), 80-93. https://doi.org/10.34021/ve.2020.03.03(5)

Received: March 18, 2020. Revised: April 24, 2020. Accepted: July 03, 2020.

(C) Author(s) 2020. Licensed under the Creative Commons License - Attribution 4.0 International (CC BY 4.0) 


\section{Introduction}

Unlike most research papers on advertising which stem from the business management and marketing schools and consider advertising at the micro level, this paper (though mainly informed by economics) studies the issue at the macro level. Generally, even works on advertising in economics tend to look at the matter from microeconomics rather than macroeconomics perspectives (Molinari \& Turino, 2006). Most economists do not consider advertising as an area worth researching. According to Stigler (1961), "advertising is treated with a hostility that economists normally reserve for tariffs or monopolists". Since the time Stigler made this declaration, over half a century ago, not much seems to have changed. This, of course, has its origin in the history of economics, pioneered by classical economists in the $19^{\text {th }}$ century (and their predecessors) who did not care to research the matter of advertising (Bagwell, 2007). Important works on economics of advertising originated in $20^{\text {th }}$ century, starting with the works by Alfred Marshal (Bagwell, 2007). Some scholars opposed advertising, seeing it as a form of ostentation encouraged by capitalism. This, they argued, can be noticed from the fact that Anglo-Saxon capitalist nations like the US and the UK promoted advertising more than, for example, European nations such as Germany and France, or even Japan. Studies on intangible investments in OECD prove that the US and the UK show high contribution to intangibles, followed by such countries as France, Denmark and Germany; while such countries as Czech Republic and Greece are grouped as catch-up countries in the third group. In the laggard group there are Italy and Spain (Ark et al., 2009). On the one hand, the positive aspect of advertising is that it assists buyers to find information about products. It, therefore, puts consumers in a better position while making their decisions about how to spend their money. According to Stigler (1961), advertising acts as means of identifying buyers and sellers in the process helping to reduce the cost of search. On the other hand, the persuasive nature of advertising is emphasized by some scholars as the one that encourages monopoly and is anti-competitive.

Information economics or economics of information is a branch of the microeconomic theory that deals with how information and information systems affect economic activities. It is concerned with how information along with the quality and value of this information affect an economy and economic decisions. Information can be inexpensively created, can be reliable, and, when reliable, is valuable (Teall, 2018). Information asymmetry means that the interacting parties have different information on the subject of the interaction; for example, one party of the transaction has more or better information than another. A mere expectation of one party to have better information than the other party leads to a change in behavior. The less informed party may try to prevent another party from taking advantage of it. Spence (1973) has originally proposed the idea of signaling in his well-known paper on job market signaling. He proposed that in a situation with information asymmetry, it is possible for people to signal their type, thus credibly transferring information to another party and resolving the asymmetry. Advertising is considered as one of the media of signaling and passing the relevant information from one party to another. According to Lippman \& McCall (2015), prior to the 1980 s, the subject of 'economics of information' meant economics of search. Research on economics of search began in the 1960s with the seminal work by Stigler (1961). Information 
economics relates to the game theory; different types of games may apply such games with perfect information, complete information. Information has economic value because it allows individuals to make choices that yield higher expected payoffs or expected utility than they would obtain from choices made in the absence of information. The game theory meaning of 'economics of information' centers on contractual relationships between parties. The incentives of parties to a contract are determined by the different information possessed by each (Lippman \& McCall, 2015). Stigler (1961) has illustrated the importance of subjecting information to economic analysis, observing that 'advertising ... is an enormously powerful instrument for the elimination of ignorance ... and is normally "paid" for by the seller.' The information technology revolution has changed the field of information economics from the condition that obtained during the time of Stigler to today's era of the internet advertising, where information is nearly free and available at the speed of light across the globe. This, further, makes advertising very essential to the modern economy: you either advertise what you are selling or the world will not know about you.

Advertising is theorized to have positive relationship with democracy, as non-democratic regimes look at advertising as part of media freedom they restricted, while democratic governments welcome the freedom that goes with advertising (Kshetri et al., 2007). In Nigeria, the period before returns to democracy in 1999 was characterized by low advertising expenditure, due to reasons mentioned above and slow economic growth of the period. This was period of military dictatorship that stifled media freedom. Expenditures in advertising are theorized to be proportionate to participation of industry and service sectors in an economy i.e. urbanization (Pesavento \& Marques, 2016). Thus, presence of industries and services in an economy is healthy for development of advertising industry. Percentage of average annual advertising expenditure in Nigeria as a ratio of average annual GDP from 2001 to 2017 is $0.069 \%$. In 2013, the period with the highest advertising revenue in the study, ratio of advertising expenditure as percentage of GDP is $0.061 \%$ which is below $0.2 \%$ a very negligible number indicating more scope for grow in the market. As a developing country, the contribution of advertising to GDP is less than is found in advanced economies. This may affect relationship between advertising and macroeconomic variables as well as the final results obtainable in study of this nature. Thus, advertising expenditure may have weak effects on macroeconomic variables in Nigeria and other developing economies. Despite that, advertising market in Nigeria has been growing since the return to democracy in 1999 (Abdullahi, 2017). Nigeria ranked among the biggest advertising market in Africa, that also included South Africa and Egypt. As largest economy in Africa, the potential of advertising market in Nigeria is bright. A recent report by PWC (2017), observed that Nigeria is on course to become world's fastest-growing Entertainment and Media (E\&M) market over the coming five years (2017-2021), growing at rate of $12.1 \%$.

Advertising form part of what is referred to as intangibles that included research and development. Intangibles has been traditionally categorized as expenses. But recently there were initiatives to categorize some intangibles as capital, some of these intangibles include software expenditure (information technology) and Research and Development (Ark et al., 2009). Intangible expenditures on software, R\&D, advertising, training, and managerial capital 
are critical investments that sustain a firm's market presence in future years through reduction in cost and raising profits beyond the current accounting period and maintaining economic competitiveness around the world. Intangibles capital around the world are concentrated in developed countries. Five countries - US, Japan, Germany, France and UK - account for 75 percent of R\&D spending in the world in 2005 (OECD, 2008). Studies have shown that intangible capital is positively related to stock market capitalization and venture capital growth (Ark et al., 2009).

\subsection{Problem statement}

There is scarcity of research on advertising and its effects on the macroeconomy in developing economies such as that of Nigeria. This paper tries to fill the gap in the literature that exists related to empirical works on effects of aggregate advertising expenditure on macroeconomics variables in Nigeria. The aim of the paper is, therefore, to provide empirical evidence that help guide businesses and policy makers in Nigeria and around the world regarding Nigerian advertising industry. The paper explores how aggregate advertising in Nigerian economy is related to macroeconomics variables such as Gross national product (GDP), aggregate consumption, foreign direct investment (FDI), inflation, savings, and stock market capitalization. Advertising expenditure which is here taken to mean aggregate advertising is defined following Molinari \& Turino (2009) as the total spending of domestic and foreign firms that advertised their products in Nigeria. The source of data used for this purpose is annual advertising expenditure generated by Media Reach (in their annual Media FactsNigeria). Media Reach started generating annual advertising expenditure in Nigeria from 2001. The methodology used for computation is correlation analysis and multiple regressions.

\section{Literature Review}

\subsection{Theoretical Literature}

All things being equal, the growth rate of advertising in developing countries should be higher than in developed countries; just like with the rate of economic growth among economies. Some academics proposed a hypothesis that the rate of advertising in emerging economies should be higher relative to those in developed economies due to the fact that advertisers' offerings to the buying populace in the developing economies are new; thus, marketers are expected to disseminate more information (Kshetri et al., 2007). Therefore, implying a higher advertising spending-sales ratio in developing countries than in developed ones, advertising budgets in the last decades has been drawn up in billions of US dollars for big multinationals. Firms take various decision as far as advertising expenditure is concerned. They can decide to sell lower quality products at a lower price with higher advertising, or decide to offer a higher quality product at a higher price with lower advertising (Feichtinger et al., 1994). Advertising generally is theorized to favor creating imperfect competition in a particular niche market. But, in some industries, instead of supporting concentration of market power in the advertising firm, advertising is theorized to be pro-competition, i.e. enhancing competition in the industry (Bearne, 1996; Bagwell, 2007). The extensive economic literature accumulated 
over centuries has not much to say regarding advertising as an important driver of macroeconomic variables. Instead, the focus has been on the market structure, investment, business cycle, research and development (R\&D), economic growth, finance, international trade, to mention just a few of the comprehensive areas of economics (Stigler, 1961; Nayaradou, 2006; Bagwell, 2007). Even within the field of advertising the focus has been on the micro analysis rather than the macro analysis. Nevertheless, there is a vast literature on advertising economics; for survey of literature see Feichtinger et al. (1994), Bearne (1996), and Bagwell (2007). Bagwell's (2007) survey is the most comprehensive. Apart from economists, other researchers interested in advertising include management scholars, media people, and psychologists. At the level of consumers, who are the target of advertisements produced daily, the education level and religious belief, among other variables, were observed as having influence on advertising messages targeted at consumers (Abdullahi, 2018).

Galbraith $(1967,1969)$ argued that advertising is an important instrument in raising national consumption level, which, in turn, helped boost the economic growth. However,, he was also critical of the wasteful nature of advertising and its effects on consumerism. Traditionally, Galbraith had different opinions on various aspects of economics, that is why he was viewed as some kind of a rebel. Theoretically, advertising only affects consumption, with advertising not having much impact on investment; whereas investment represents the alternative option for the consumer who does not want to consume (Molinari \& Turino, 2009). There is a hypothesis in the literature that considers advertising as cyclically moving together with the economy. Thus, during recession the volume of advertising goes down, while in period of boom the advertising volume increases. There also exists another hypothesis that sees advertising as anticyclical. According to Hall (2014), advertising should be countercyclical, rising during recession and falling during the period of growth. It is argued so because firms need to advertise aggressively during a slump period in order to boost the sales growth. But, the reality, according to Hall's findings, is that advertising is cyclical. For example, those who consider advertising as investment argue that just like investment that is cyclical and depreciative, advertising is also cyclical and has higher depreciation rate than tangible investment (Hall, 2014). Thus, scholars knowing the matter favor advertising as being cyclical rather than anti-cyclical. The advertising industry's actors also seem to have the same viewpoint. Foreign direct investment (FDI) is linked with an advertising increase in the receiving country, as multinational corporations investing in the receiving country build their marketing and advertising activities (Kshetri et al., 2007). Hence, based on this, FDI should be positively related to advertising. Yet this view, just like most matters in advertising, is not universally held.

\subsection{Empirical Literature}

The economic growth goes hand in hand with advertising expenditure, which, according to study by (Wurff et al., 2008; Molinari \& Turino, 2009), is more pronounced in the case of advertising spending in newspapers. According to Picard (2001), the print media are more affected by recession than the broadcast media in the ratio of 4 to 1 . Bughin \& Spittaels (2012) found that advertising has fueled, on average, about 15 percent of GDP growth for the major 
G20 economies for over a decade. Rehme \& Weisser (2007) found the effect of advertising on consumption to be positive in the short run but negative in the long run. This means the advertising impact is immediate and does not last. This is consistent with the human memory, which is short. Kshetri et al. (2007) found that advertising spending in the economy is driven by the income level and FDI inflow. In their study on relationship between aggregate advertising and aggregate consumption spending, Ashley et al. (1980) observed that advertising did not cause consumption; on the other way round, they found some evidence suggesting that consumption might cause advertising. Another study (Rehme \& Weisser, 2007) found that advertising did not Granger-cause growth but Granger-caused consumption, which, in turn, Granger-caused the GDP growth. So, an advertising effect on the economic growth is through consumption. Using a general equilibrium context, Molinari \& Turino (2009) found the impact of advertising on consumption to be very strong. Molinari \& Turino (2006) calculated that advertising expenditures were positively correlated to both consumption and investment, and they were more volatile than consumption but less than investment and durable consumption. Studying the UK advertising industry, Sturgess (1982) found that the results of his analysis did not support the hypothesis that total advertising expenditures altered aggregate consumer behavior. He tested causality using data covering the period from 1969 to 1980.

Empirical works (Molinari \& Turino, 2006; Molinari \& Turino, 2009; Bughin \& Spittaels, 2012) show positive correlation between advertising and the economic growth, thus, further supporting the argument that advertising is pro-cyclical. Picard (2001) also found out that advertising expenditure declined during the time of recession by an average of $5 \%$ when there is decline of $1 \%$. Empirical literature on advertising has largely remained inconclusive and controversial (Bagwell, 2007; Molinari \& Turino, 2006). For example, Nayaradou (2006) in his $\mathrm{PhD}$ thesis on advertising and economic growth found a positive correlation between the advertising investment rate and productive efficiency (which is by itself an original indicator of the economic growth efficiency). The greater is the increase in advertising investment rate, the greater is the increase in productive efficiency (and vice versa). However, this is not to maintain that advertising directly causes the economic growth; it is just a correlation which may be a result of boom in investments or consumption in those sectors. Thus, this is short of providing a causality direction. Yet in his conclusion Nayaradou (2006) observed that an advertising effect on the growth was through a channel of stimulating consumption, innovation and competition. Chen \& Waters (2017) found that advertising expenditures were directly related to profits for industries with significant advertising expenditures. Bughin \& Spittaels (2012) also found that advertising (especially digital advertising) improves the company performance. Other studies like that of Metwally (1975) on advertising expenditures of Australian firms revealed its contribution to profit to be inconclusive. Joshi \& Hanssens (2009) empirically tested an effect of advertising on the firm's own market capitalization in the long run. Their findings showed its effect was positive on the firm's capitalization and might have a negative impact on valuating a competitor of a comparable size.

Martínez-Fernández et al. (2014) used a cointegration analysis to measure effects of advertising investment on macroeconomic variables such as GDP, the national income, 
savings, consumption, and fixed capital formation in Spain. Their findings showed the so-called Galbraith's hypothesis did not work in a Spanish case. Using the data on the US economy, Molinari \& Turino (2006) found that the result of their findings confirmed the Galbraith's conjecture that advertising affects not only the total amount of consumption expenditures but also the output composition. The scholars also observed that advertising resulted in inducing a strong substitution effect between consumption and leisure. Chowdhury (1994) reinvestigates the relationship between advertising expenditures and macro-variables using the aggregate data from the United Kingdom. Adopting cointegration and a causality approach his analysis fails to show any meaningful relationship between advertising expenditure and the level of the national income, disposable income, and personal consumption expenditures. Yet, there was only found a strong uni-directional causality existing from advertising activity to unemployment rate. In their study on advertising using a dynamic stochastic general equilibrium (DSGE) model, Molinari \& Turino (2006) observed that advertising expenditures have non-negligible effects on the aggregate economy in the long run and short run. The study by Pesavento \& Marques (2016) in Brazil showed that inflation had negative impacts on advertising expenditure. While empirical evidence of the role of advertising in deterring new competitors from entering a market has been mixed, 'the appropriate interpretation of advertising-entry relationship is subtle and seems to vary across industries' (Bagwell, 2007). Regarding the advertising-price relationship, Bagwell's (2007) survey also found the evidence to be mixed; and also inconclusive in case of the advertising-quality relationship.

\section{Data and Methodology}

\subsection{Data}

Two sets of data informed this study: the first set used to analyze our multiple regression model comprises the quarterly data of advertising revenue, consumption, GDP and inflation from 2010 to 2018. The second set encompasses the annual data of advertising revenue, consumption, foreign direct investment, savings, stock market capitalization, GDP, and inflation from 2001 to 2017. The second set of data was used to make correlation analysis of the variables in the study. The data for the study were selected based on their relevance to the advertising industry and their significance as major variables determining what happens in the wider economy. The study period covered the most recent time for which the annual advertising expenditure data in Nigeria is available. The data for a longer period is not available, which is the reason why the study is exploratory in its nature. It also explains the choice of methods for analysis. The study, among others things, attempts to find out the dynamic regression and cross correlation among the variables studied. The data was sourced from Media Reach (annual Media Facts) for aggregate advertising expenditure and the Nigerian Bureau of Statistics (NBS) and Index Mundi (www.indexmundi.com) for macroeconomic variables data. Statistical analysis was adopted to explain individual variables and how they relate with one another.

\subsection{Multiple Regression Analysis}


A multiple regressions model of analysis is employed in testing the relationship between the variables in the study. The model takes quarterly advertising expenditure in the economy as dependent on consumption, gross domestic products and inflation. The estimation method that is most commonly used with regression models is that of least squares. It is derived by using the method of moments, which is a very general principle of estimation that has many applications in econometrics (Davidson \& MacKinnon, 1999). Generally, regression analysis has remained the most commonly used method in estimating econometric relationship.

The model:

$$
\operatorname{adexp}=\beta_{0}+\beta_{1 c s m}+\beta_{2 g d p}+\beta_{3 i n f}+\mu
$$

where adexp is annual advertising expenditure;

csm is aggregate consumption;

gdp is gross domestic products;

inf is inflation;

$\beta$ is parameters;

$\mu$ is error term.

\subsection{Correlation}

Correlation analysis is employed to find out the relationship between advertising expenditure and respective variables in the study. According to Zaman (1996), elementary graphical and exploratory data analysis often produces good results which can be supported by the advanced method of data analysis. Correlation is often used to suggest hypotheses or to confirm those previously held suspicious (Pindyck \& Rubinfeld, 1998). The correlations here are, thus, computed to measure the strength of association among our sampled variables.

\section{Results and Discussions}

\subsection{Multiple Regressions}

The multiple regressions analysis shows that there is a negative and statistically significant relationship between quarterly advertising expenditure and consumption. This may be a result of many factors, one of which includes the fact that organization that spends hardly on advertising takes into consideration quarterly consumption spending, their eyes are on the annual spending. Second, an increase in consumption may lead to advertisers' being satisfied with their advertising level, and thus, to refusing to increase the level of advertising spending. Third, the nature of the consumption expenditure is connected to GDP (calculated by expenditure), which comprises different types of consumption expenditures including those that are not directly influenced by advertising. 
- regress advertexp cons gdp infl

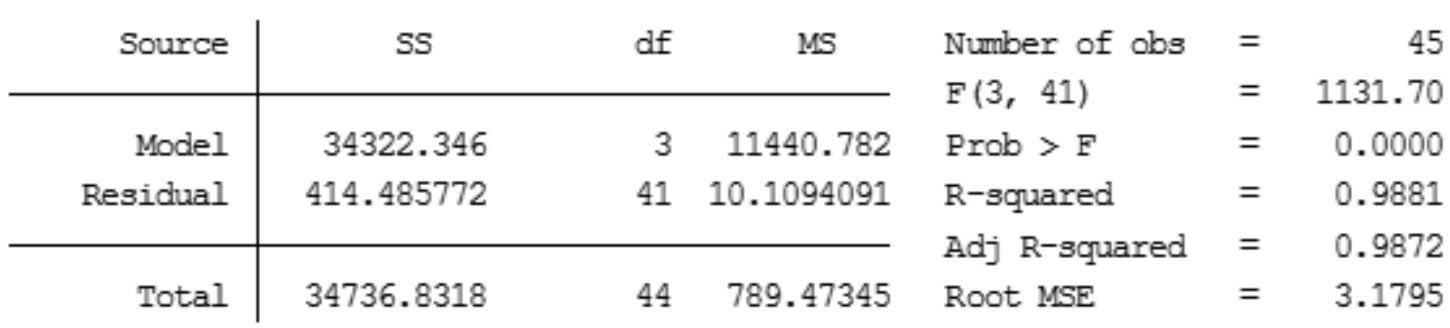

\begin{tabular}{r|rrrrrr}
\hline advertexp & Coef. & Std. Err. & $t$ & P>|t| & [958 Conf. Interval] \\
\hline cons & $-6.55 \mathrm{e}-07$ & $6.74 \mathrm{e}-08$ & -9.73 & 0.000 & $-7.91 \mathrm{e}-07$ & $-5.19 \mathrm{e}-07$ \\
gdp & $2.14 \mathrm{e}-06$ & $7.03 \mathrm{e}-08$ & 30.37 & 0.000 & $1.99 \mathrm{e}-06$ & $2.28 \mathrm{e}-06$ \\
infl & .1305281 & .4302135 & 0.30 & 0.763 & -.7383056 & .9993619 \\
cons & .0546016 & .8384016 & 0.07 & 0.948 & -1.638585 & 1.747788 \\
\hline
\end{tabular}

Figure 1. The Result of Multiple Regressions

Source: developed by the authors.

The fact that consumption spending is a subset of GDP may have brought about the problem of multicollinearity in the analysis. This has to be noted in considering the result of the analysis. Multicollinearity is usually a problem in most regression analyses, but this does not mean that the entire result is not blind. The main effect of the problem is in making the result less efficient. The fact that we have no choice over the data used for the analysis makes the problem inevitable. Besides, the sign of the consumption coefficient is statistically significant. See Gujarati et al. (2012) for a detail analysis of the phenomenon of multicollinearity. For the other variables, advertising expenditure is positively related to GDP; this result was also predicted by the theory. This means that an increase in GDP leads to an increase in advertising expenditure and vice versa. The result also shows that the influence of inflation on advertising expenditure is not significant. The model has significant predictive capacity with an adjusted $\mathrm{R}$ of 0.98 .

\subsection{Results of Correlation Analysis}

1 - Advertising-Consumption: the level of correlation between advertising and consumption is strong at 0.88 . This means that higher advertising may be responsible for higher consumption and/or the other way round; that is higher consumption is responsible for higher advertising. They might be linked through the higher GDP that both of them are highly correlated. Thus, both advertising practitioners, businesses and government must watch movements in consumption as a good indicator of future prospects of the advertising industry when they are planning for their businesses. Higher consumption expenditure in the economy is a good indicator of time to start advertising by firms and other agencies. While, lower consumption expenditure means it is a poor time to advertise to the consuming public as they have lower 
propensity to consume. The higher level of advertising may also have the effect of making people to consume more, hence the high positive correlation between advertising expenditure and consumption. The differences in the nature of data used for multiple regression analysis may have explained why the result differs from the result here.

Table 1. Results of Correlation Analysis

\begin{tabular}{|c|c|c|c|c|c|c|c|}
\hline \multicolumn{2}{|c|}{$\begin{array}{c}\text { Covariance Analysis: } \\
\text { Ordinary }\end{array}$} & \multicolumn{2}{|c|}{$\begin{array}{c}\text { Date: } 26 / 05 / 20 \text { Time: } \\
15: 17 \\
\end{array}$} & \multicolumn{2}{|c|}{ Sample: 20012017} & \multicolumn{2}{|c|}{ Included observations: 17} \\
\hline $\begin{array}{l}\text { Correlation } \\
\text { t-Statistic } \\
\text { Probability }\end{array}$ & ADV & CSM & FDI & GDP & INF & NSE & SAV \\
\hline ADV & $\begin{array}{r}1.000000 \\
----- \\
---- \\
\end{array}$ & & & & & & \\
\hline CSM & $\begin{array}{r}0.881115 \\
7.216165 \\
0.0000 \\
\end{array}$ & $\begin{array}{r}1.000000 \\
---- \\
----- \\
\end{array}$ & & & & & \\
\hline FDI & $\begin{array}{r}0.644370 \\
3.263491 \\
0.0052 \\
\end{array}$ & $\begin{array}{r}0.322587 \\
1.319937 \\
0.2066\end{array}$ & $\begin{array}{r}1.000000 \\
---- \\
----\end{array}$ & & & & \\
\hline GDP & $\begin{array}{r}0.903657 \\
8.172306 \\
0.0000\end{array}$ & $\begin{array}{r}0.970481 \\
15.58455 \\
0.0000\end{array}$ & $\begin{array}{r}0.398200 \\
1.681264 \\
0.1134\end{array}$ & $\begin{array}{r}1.000000 \\
---- \\
----\end{array}$ & & & \\
\hline INF & $\begin{array}{r}-0.295219 \\
-1.196716 \\
0.2500 \\
\end{array}$ & $\begin{array}{r}-0.290030 \\
-1.173733 \\
0.2588 \\
\end{array}$ & $\begin{array}{r}-0.209817 \\
-0.831119 \\
0.4189\end{array}$ & $\begin{array}{r}-0.364287 \\
-1.514975 \\
0.1506 \\
\end{array}$ & $\begin{array}{r}1.000000 \\
---- \\
----\end{array}$ & & \\
\hline NSE & $\begin{array}{r}0.647389 \\
3.289765 \\
0.0050\end{array}$ & $\begin{array}{r}0.618205 \\
3.046112 \\
0.0082 \\
\end{array}$ & $\begin{array}{r}0.553819 \\
2.576070 \\
0.0211 \\
\end{array}$ & $\begin{array}{r}0.675920 \\
3.552126 \\
0.0029\end{array}$ & $\begin{array}{r}-0.630823 \\
-3.148708 \\
0.0066 \\
\end{array}$ & $\begin{array}{r}1.000000 \\
---- \\
----\end{array}$ & \\
\hline SAV & $\begin{array}{r}0.783158 \\
4.877855 \\
0.0002\end{array}$ & $\begin{array}{r}0.768614 \\
4.653376 \\
0.0003\end{array}$ & $\begin{array}{r}0.464762 \\
2.032915 \\
0.0602\end{array}$ & $\begin{array}{r}0.892569 \\
7.666491 \\
0.0000\end{array}$ & $\begin{array}{r}-0.371169 \\
-1.548122 \\
0.1424\end{array}$ & $\begin{array}{r}0.615658 \\
3.025880 \\
0.0085\end{array}$ & $\begin{array}{r}1.000000 \\
----- \\
-----\end{array}$ \\
\hline
\end{tabular}

Source: developed by the authors.

2 - Advertising-GDP: advertising and GDP have the strongest correlation of any two variables in the study with correlation of 0.9 to GDP. This gives credence to previous studies that found strong relationship between advertising and GDP in other economies around the world. Thus, during the periods of strong rally in the economy, advertising tends to grow with the economy, and during periods of recession or slowdowns, the advertising level declines. Advertising also causes consumers to purchase more goods and services helping the economy to continue growing. So, media agencies look at the growth in advertising by businesses and government as a good sign of time when advertising revenue starts coming in. During the economic slowdown, just like other businesses, media companies strategize and tighten up as a sign of more difficult time to come. Advertising has a positive effect on economic growth; and economic growth also influences advertising positively. 
3 - Advertising-Inflation: advertising has a negative, but statistically insignificant, relationship with inflation. A previous study (Pesavento \& Marques, 2016) showed that advertising has a negative relationship with inflation in Brazil.

4 - Advertising-Savings: savings is another variable that has good correlation with advertising at 0.78 . This may point to the fact that companies and individuals save when they have surpluses above their budgeted consumption expenditure. It, therefore, serves as a good indicator of the economy's performance. Savings can also serve as a source of money for financing advertising expenditure for firms and households. Though, this may only happen in rare occasions when advertising is urgent or is demanded by necessity. Savings relation to investment may also help in explaining these relationships.

5 - Advertising-FDI-Stock Market Capitalization: Foreign Direct Investment (FDI) and stock market capitalization have almost identical correlation with advertising at 0.644 and 0.647 , respectively. This is due to the fact that stock market is one of the main corridors through which foreign investments come into the Nigerian economy. They also serve as major indicators of the economy's performance. Multinational corporations investing in Nigeria build their marketing and advertising activities during the period of rising advertising expenditure. Thus, based on this, FDI and stock market capitalization is positively related to advertising. High FDI and capitalization also mean that Nigeria-based firms and their foreign collaborators have the surplus capacity and the business motivation to advertise. The reverse is also the case where lower FDI and capitalization usher in a lower business activity and a desire to lower expenditures such as that of advertising. Some FDI are directed towards marketing and advertising industry, thus, helping the industry development.

\subsection{Implications of the Study}

Macroeconomic variables have an important role to play in shaping the state of advertising industry. It acts as an important barometer of the industry performance. The performance of these variables heralds the coming of good things for the advertising sector, while a poor performance by the same variables heralds the difficult times ahead for the sector. Previous studies such as Lee et al. (2011) showed that advertisers (in financial services industry) increased the level of informative advertisement after financial/economic crisis in order to boost their market appeal, but the increase was at a declining rate when compared to the period of an economic boom. This indirectly supports the finding of this paper and previous works on this topic that advertising is countercyclical. Managers and advertising practitioners should pay more attention to macroeconomic variables rather than to the level of attention they are giving to these variables at the moment, because their successes and failures depend on them. Over the years, the Nigerian advertising industry has grown in terms of the market size and employment generation. The fact that the industry is sensitive to happenings in the economy has implications on the economic lives of all the major stakeholders in the industry who include workers, investors, advertising public and revenue collection agencies.

\section{Conclusions}


Globally, advertising is a billions-of-dollars industry that contributed to creating jobs and national income. This paper has demonstrated links between some important macroeconomics variables and advertising expenditure in Nigeria. This further debunks the view that advertising has little to say regarding policy-making by governments at various levels. The study is unique due to the types of variables involved and the scarcity of this type of works on the Nigerian advertising market. Advertising is sometimes viewed as of concern to only business units and as not worth researching at the macroeconomic level. Studies of this nature have mostly been conducted on advanced economies' advertising industries. The general lackluster attitude toward advertising shown by the government should stop. Advertising is a money-spinner at the heart of success of the internet giants such as Facebook, Google and Yahoo. Thus, no any serious government around the world will leave the industry on its own in terms of coopting it into a government policy-making framework.

One drawback of this research is in data generation. There is scarcity of long-term time series data for this kind of study in a developing economy like that of Nigeria. Only availability of data going back into years and/or availability of high frequency data will make it possible to conduct a rigorous analysis enabled by modern econometric packages. Thus, this research will remain an exploratory study acting as a guide for business and decision makers.

\section{References}

Abdullahi, S. I. (2017). Islamic Advertising in Nigeria: An Assessment. International Journal Islamic Marketing and Branding, 2(1), 65-84. https://doi.org/10.1504/IJIMB.2017.10004205

Abdullahi, S. I. (2018). Measuring Consumer Perception of Ethical Issues in Advertising: Evidence from Nigerian Advertising Audience. Middle East Journal of Management, 5(3), 191-206. https://doi.org/10.1504/MEJM.2018.10014703

Ark, B., Hao, J.X., Corrado, C., \& Hulten, C. (2009). Measuring Intangible Capital and its Contribution to Economic Growth in Europe. EIB Papers, 14(1), 62-93.

Ashley, R., Granger, C. W. J. \& Schmalensee, R. (1980). Advertising and Aggregate Consumption: An Analysis of Causality. Econometrica, 48(5), 1149-1167. https://doi.org/10.2307/1912176

Bagwell, K. (2007). The Economic Analysis of Advertising. In M. Armstrong \& R. Porter (Eds.), Handbook of Industrial Organization (pp. 1701-1844). Amsterdam: North-Holland Publishing.

Bearne, A. (1996). The Economics of Advertising: A Reappraisal. Economic Issues, 1(1), 23-38.

Bughin, J. \& Spittaels, S. (2012). Advertising as an Economic-Growth Engine: The New Power of Media in the Digital Age. Chicago: McKinsey \& Company.

Chen, J. \&Waters, G. (2017). Firm Efficiency, Advertising and Profitability: Theory and Evidence. The Quarterly Review of Economics and Finance, 63, 240-248. https://doi.org/10.1016/j.qref.2016.04.004

Chowdhury, A.R. (1994). Advertising Expenditures and the Macro-Economy: Some New Evidence. International Journal of Advertising. The Review of Marketing Communications, 13(1), 1-14. 
Davidson, R., \& MacKinnon, J. G. (1999). Econometric Theory and Methods. Oxford: Oxford University Press.

Feichtinger, G., Hartl, R.F., \& Sethi, S.P. (1994). Dynamic Optimal Control Models in Advertising: Recent Developments. Management Science, 40(2), 195-226.

Galbraith, J.K. (1967). The New Industrial State. Boston: Houghton Mifflin.

Galbraith, J.K. (1969). The Affluent Society. Boston: Houghton Mifflin.

Gujarati, D.N., Porter, D.C., \& Gunasekar, S. (2012). Basic Econometrics. New Delhi: Tata-Mc Graw Hill Ltd.

Hall, R.E. (2014). What the Cyclical Response of Advertising Reveals about Markups and other Macroeconomic Wedges. Retrieved from https://www.frbsf.org/economicresearch/files/Fri_1340_Hall.pdf

Joshi, A., \& Hanssens, D.M. (2010). The Direct and Indirect Effects of Advertising Spending on Firm Value. Journal of Marketing, 74(1), 20-33. https://doi.org/10.1509/jmkg.74.1.20

Kshetri, N., Williamson, N.C., \& Schiopu, N. (2007). Economics and Politics of Advertising: Evidence from the Enlarging European Union. European Journal of Marketing, 41, 349-366.

Lee, T., Chung, W., \& Taylor, R.E. (2011). A Strategic Response to the Financial Crisis: An Empirical Analysis of Financial Services Advertising before and during the Financial Crisis. Journal of Services Marketing, 25(3), 150-164. https://doi.org/10.1108/08876041111129146

Lippman, S.S. \&McCall, J.J. (2015). Economics of Information. In J. Wright (Ed.), International Encyclopedia of the Social \& Behavioral Sciences, 2nd ed. New York: Elsevier.

Martínez-Fernández, V., Castellanos, P., \& Juanatey-Boga, O. (2014). Advertising Investment as a Tool for Boosting Consumption: Testing Galbraith's Hypothesis for Spain. Revista de Economia Contemporânea - Journal of Contemporary Economics, 18(3), 435-452.

Metwally, M. M. (1975). Advertising and Competitive Behaviour of Selected Australian Firms. The Review of Economics and Statistics, 57(4), 417-427.

Molinari, B., \& Turino, F. (2006). The Role of Advertising in the Aggregate Economy: The Work and Spend Cycle. Retrieved from http://citeseerx.ist.psu.edu/viewdoc/download?doi=10.1.1.520.6821\&rep=rep1\&type=pdf

Molinari, B., \& Turino, F. (2009). Advertising and Business Cycle Fluctuations. Retrieved from https://editorialexpress.com/cgi-bin/conference/download.cgi?db_name=MMF2010\&paper_ id $=160$

Nayaradou, M. (2006). Advertising and Economic Growth. Doctorate Thesis in Economics. Paris: University of Paris-Dauphine, World Federation of Advertisers (WFA) and French Association of Advertisers.

OECD. (2008). OECD Science, Technology and Industry Scoreboard. Paris. Retrieved from https://www.oecd.org/sti/inno/oecdsciencetechnologyandindustryoutlook2008.htm

Picard, R.G. (2001). Effects of Recessions on Advertising Expenditures: An Exploratory Study of Economic Downturns in Nine Developed Nations. The Journal of Media Economics, 14(1), 1-14. https://doi.org/10.1207/S15327736ME1401_01 
Pindyck, R.S., \& Rubinfeld, D.L., (1998). Econometric Models and Economic Forecasts. Boston: Irwin/McGraw-Hill.

Pesavento, F., \& Marques, A. M. (2016). Advertising Expenditures in Brazil and its Connection with the International Economy. REBRAE Curitiba, 9(1), 43-61. http://dx.doi.org/10.7213/rebrae.v9i1.14192.g13628

PWC. (2017). Nigeria will Be the World's Fastest Growing E\&M Market- PwC Report. Retrieved from https://www.pwc.com/ng/en/press-room/nigeria-will-be-the-worlds-fastest-growing-e-mmarket-pwc-report.html

Rehme, G., \& Weisser, S.-F. (2007). Advertising, Consumption and Economic Growth: An Empirical Investigation. Darmstadt Discussion Papers in Economics, 178, 1-43

Spence, M. (1973). Job Market Signaling. The Quarterly Journal of Economics, 87(3), 355-374.

Stigler, G. J. (1961). The Economics of Information. The Journal of Political Economy, 69(3), 213-225.

Sturgess, B. T. (1982). Dispelling the Myth: The Effects of Total Advertising Expenditure on Aggregate Consumption. International Journal of Advertising. The Review of Marketing Communications, 1(3), 201-212.

Teall, J. L. (2018). Financial Trading and Investing. Cambridge: Academic Press.

Wurff, R. V., Bakker, P., \& Picard, R. G. (2008). Economic Growth and Advertising Expenditures in Different Media in Different Countries. Journal of Media Economics, 21(1), 28-52. https://doi.org/10.1080/08997760701806827

Zaman, A. (1996). Statistical Foundations for Econometric Techniques. Oxford: Academic Press. 